\title{
Association of Vitamin D Deficiency and Inflammatory Cytokines with the Clinicopathological Features of Breast Cancer in Female Saudi Patients
}

\author{
Amal F. Gharib
}

Taif University

Ahmad El Askary ( $\nabla$ a.elaskary@tu.edu.sa )

Taif University https://orcid.org/0000-0002-6022-0772

Mazen Almehmadi

Taif University

Wael H. Elsawy

Zagazig University Faculty of Human Medicine

Hatem H. Allam

Taif University

Lamiaa K. Elsayyad

Taif University

Manal Ali Ayoub

Taif University

Alaa Shafie

Taif University

\section{Research}

Keywords: Vitamin D, Inflammatory Cytokines, Breast Cancer

Posted Date: February 25th, 2021

DOl: https://doi.org/10.21203/rs.3.rs-262782/v1

License: (9) This work is licensed under a Creative Commons Attribution 4.0 International License. Read Full License 


\section{Abstract}

Background: Breast cancer is considered to be the most common leading cause of cancer related death among women in Saudi Arabia. Many researches supposed a strong correlation between vitamin $D$ and different types of cancer.

Patients and methods: We aimed to study the implication of serum vitamin D, calcium, interleukin 6 (IL6), tumor necrosis factor alpha (TNF-a) and chemerin on progression of breast cancer. One hundred female Saudi patients were included in the current research and we assessed their serum levels of vitamin $D$, calcium, IL-6, TNF-a and chemerin.

Results: vitamin $D$ was significantly decreased in tumors with high grade $(P<0.0001)$, patients with obesity $(P=0.013)$, negative estrogen receptors $(E R)(P<0.0001)$, negative progesterone receptors $(P R)(P<$ $0.0001)$ and positive HER2 receptors $(P<0.0001)$. It was also decreased in large tumors $(P<0.0001)$, patients with axillary lymph node involvement $(P<0.0001)$ and in the patients with advanced clinical stage $(P<0.0001)$. Moreover, higher levels of serum IL-6, TNF-a, chemerin were significantly related to breast cancer and its advanced stages.

Conclusion: vitamin D deficiency and elevated inflammatory cytokines (IL6, TNF-a and chemerin) are associated with breast cancer progression in female Saudi patients.

\section{Introduction}

Breast cancer has been recognized as the leading cause of cancer-related death in women worldwide, and it constitutes around one-third of all female malignancies [1]. In 2018, nearly 2,088,000 new breast cancer cases were diagnosed, and 6,260,000 deaths from breast cancer were recognized [2]. It is the most common malignant tumor in Saudi women with a prevalence rate of $21.8 \%$; it represents the ninth cause of death among them [3].

Vitamin D deficiency is considered communal health distress worldwide. In Saudi Arabia, vitamin D deficiency is around $60 \%$. Its occurrence was reported in different ages and both gender among the Saudi population $[4,5]$. Serum $25(\mathrm{OH}) \mathrm{D}$ levels were determined as the best biomarker to measure vitamin $\mathrm{D}$ status due to its greater half-life and stability in circulation versus the active form of vitamin $D$ [6]. The deficiency of vitamin D was defined as serum $25(\mathrm{OH})$ D level of $\otimes 20 \mathrm{ng} / \mathrm{ml}$, vitamin $D$ insufficient as $20-30 \mathrm{ng} / \mathrm{ml}$, and vitamin $\mathrm{D}$ sufficient as $>30 \mathrm{ng} / \mathrm{ml}[7]$.

Substantial scientific evidence has been revealed a strong relationship between vitamin D and Cancer [8]. The protective role of vitamin $\mathrm{D}$ against breast cancer was supported by the results of a recent study that proved a significant relationship between low serum vitamin $D$ and high risk of breast cancer [7]. The protective effect of calcium against breast cancer risk is thought to be majorly triggered by chemopreventive action of the active form of vitamin $D$, which is the major regulator of calcium homeostasis [9]. 
Vitamin D deficiency may lead to uncontrolled metabolic syndromes that result in carcinogenesis [10]. The biologically active form of vitamin $\mathrm{D}\left(1,25(\mathrm{OH})_{2} \mathrm{D}_{3}\right)$ was produced in the kidney by the action of 1-alpha hydroxylase (CYP27B1). CYP27B1 is produced by other tissues and immune cells that can regulate their local amounts of active vitamin D through it [11]. The expression of CYP27B1 in the immune cells is triggered either by the presence of the cytokines directly [12] or through immune regulatory mechanisms associated with vitamin $\mathrm{D}$ receptor activation [13].

The deficiency of vitamin D may result in immune cell dysfunction [14] and cytokine variability $[15,16]$. It was noted that adequate levels of 25(OH)D are associated with increasing levels of IL-4 and IL-10 and decreasing the pro-inflammatory cytokines such as IL-1, IL-6, IL-8, and TNF-a. Vitamin D is down-regulating the expression and production of these pro-inflammatory cytokines [17].

The effect of pleiotropic cytokines on cancer development was established. The treatment efficacy and prognosis in malignant diseases were assessed by the disease stage and by the function of immune system pathways mediated by IL-6, IL-8, and TNF-a $[18,19]$.

The inflammatory pathogenic environment of breast cancer may represent an additional mechanism that may associate the chemerin expression with breast cancer [20]. Chemerin is an adipocytokine regulating different immunological and biological functions. Chemerin exerts most of its effects through the chemokine-like receptor 1 (CMKLR 1), expressed by many cells [21. 22]. It possesses variable links with inflammation and metabolism of the cells as well as cellular differentiation. Chemerin release is governed by various mediators as vitamin $\mathrm{D}$, retinoid, and corticosteroids, in addition to the cytokines that regulate acute and chronic inflammation [23].

Chemerin was linked to the pro-inflammatory cytokines that mediate the cytotoxic cellular immunity as IL-6, II-8, and TNF-a; they were considered as inflammatory promoters for breast carcinogenesis [24, 25].

Through the prevalent anticancer actions and specific signaling pathways of active vitamin $D$ in breast cancer and according to epidemiological evidence, vitamin D may have a protecting role against breast cancer. Furthermore, this meta-analysis revealed a significant dose-response association between circulating vitamin $\mathrm{D}$ and overall survival in breast cancer patients [26].

In the currents study, we aimed to evaluate the association of vitamin D deficiency and some inflammatory cytokines, with the progression of breast cancer in Saudi female patients.

\section{Patients And Methods}

\section{Study design and population}

This is a case control study, was conducted at the College of Applied Medical Sciences, Taif University, Taif. It included one hundred Saudi female patients with early or locally advanced breast cancer. The patients were recruited from King Faisal Hospital in Taif city, during the period between January 2020 to September 2020. All patients were histopathologically confirmed and clinically staged based on the American Joint 
Committee of Cancer (AJCC) staging system [27]. Their ages ranged between 20 and 80 years. One hundred healthy females free from any cancer diagnosis were included as controls. They were matched with patients by age and residence area and not receiving vitamin $\mathrm{D}$ supplementation.

Inclusion criteria: female patients early diagnosed or locally advanced breast cancer and not metastasized.

Exclusion criteria: we excluded the following: patients receiving any vitamin D supplementation or anticancer (hormonal, chemo- or radiotherapy), patients with other types of cancer or metastasis.

Before entry in the study, All patients had a careful history, physical examination, complete blood picture (CBC), liver and kidney function tests, chest X-ray, pelvic abdominal ultrasonography, echocardiogram, magnetic resonance imaging of both breasts, and isotopic bone scan. Hormone receptors estrogen, progesterone, and HER2 receptors were determined by immunohistochemistry using SP1, 1E2 and 4B5 (Ventana) antibodies, respectively. The weight (kilograms) and height (meters) were measured to calculate the body mass index $(\mathrm{BMI})$ by the equation = Weight $(\mathrm{kg}) /$ height $\left(\mathrm{m}^{2}\right)$.

\section{Blood samples}

We obtained $5 \mathrm{ml}$ of venous blood from all included participants.

The samples remained at room temperature for 1 hour to clot in the serum separator tubes and centrifuged for 5 minutes at $3000 \mathrm{rpm}$. The sera were collected and stored at $-20^{\circ} \mathrm{C}$ until analysis.

Informed written consent was taken from each participant in addition to the approval of the Research Ethics Committee of Taif University (approval no.

$42-0010)$.

\section{Methods}

\section{Estimation of serum 25(OH)D level by enzyme-linked immunosorbent assay (ELISA)}

25(OH)D level was estimated in serum samples from all included females using Abcam human vitamin $D$ ELISA kit, USA (Cat No: ab213966) conferring in the protocol manufacturers. The range of detection was 0.5 $-1010 \mathrm{ng} / \mathrm{mL}$, and the sensitivity of the assay was $1.98 \mathrm{ng} / \mathrm{mL}$ Serum vitamin D level less than $20 \mathrm{ng} / \mathrm{ml}$ was considered deficient.

\section{Estimation of serum interleukin-6 (IL 6), tumor necrosis factor (TNFa) and chemerin levels by ELISA}

Serum levels of IL 6 were estimated in all participant samples by ELISA kit (MyBioSource, USA; Cat No MBS261259), with detection range $300-4.7 \mathrm{pg} / \mathrm{ml}$ and a sensitivity up to $1 \mathrm{pg} / \mathrm{mL}$. The serum TNF-a levels were assayed using the Abcam human TNF-a ELISA kit, UK (ab181421), with a sensitivity $4.32 \mathrm{pg} / \mathrm{mL}$ and detection range $15.63-1000 \mathrm{pg} / \mathrm{ml}$. The serum chemerin concentration was quantified using Abcam human chemerin ELISA kit (ab155430) with sensitivity $0.5 \mathrm{ng} / \mathrm{ml}$ and detection range $0.51-50 \mathrm{ng} / \mathrm{ml}$, according to the manufacturer's guidelines.

\section{Estimation Of Serum Calcium}


Serum calcium was estimated by calcium colorimetric assay kit, Abcam, USA (Cat No: ab102505) with detection range $0.4-100 \mathrm{mg} / \mathrm{dL}$ according to the manufacturer's protocol.

\section{Statistical Analysis}

Analysis of our data was performed by SPSS 10.00 software (SPSS Inc., Chicago, IL, USA). The one -way analysis of variance (ANOVA) and the Student's t-test were considered to evaluate the statistical significance between different variables. Pearson correlation coefficient was used to assess the association between vitamin $D$ and other studied parameters. P values were considered statistically significant at < 0.05 .

\section{Results}

The current study included 100 Saudi female patients with early or locally advanced breast cancer. Their age ranged between 20 and 80 years. There were 37 patients suffering from obesity. Fifty-three were post-menopausal. Infiltrative duct carcinoma (IDC) were histopathologically diagnosed in 84 patients. The Patient's characteristics are presented in Table 1. 
Table 1

Patient's characteristics

\begin{tabular}{|lc|}
\hline Age & No. \\
\hline Age group & \\
\hline $20-30$ & 6 \\
\hline $31-40$ & 16 \\
\hline $41-50$ & 40 \\
\hline $51-60$ & 20 \\
\hline $61-70$ & 11 \\
\hline $71-80$ & 7 \\
\hline BMI & 29 \\
\hline Normal weight & 34 \\
\hline Over weight & 37 \\
\hline Patients with obesity & \\
\hline Menopausal status & \\
\hline Premenopausal & 47 \\
\hline Postmenopausal & 53 \\
\hline Pathology & 24 \\
\hline IDC & 24 \\
\hline ILC & 16 \\
\hline Pathological grade & \\
\hline I & 24 \\
\hline II & 24 \\
\hline III & \\
\hline IV & \\
\hline Estrogen receptors (ER) \\
\hline Positive & \\
\hline Negative & \\
\hline Progesterone receptors (PR) \\
\hline Positive
\end{tabular}




\begin{tabular}{|ll|}
\hline Age & No. \\
\hline Negative & 22 \\
\hline HER2 receptors & \\
\hline Positive & 26 \\
\hline Negative & 74 \\
\hline T & \\
\hline T1 & 25 \\
\hline T2 & 50 \\
\hline T3 & 25 \\
\hline N & \\
\hline N0 & 33 \\
\hline N1 & 36 \\
\hline N2 & 31 \\
\hline TNM stage & \\
\hline I & 13 \\
\hline IIA & 27 \\
IIB & 27 \\
\hline IIIA & 33 \\
\hline
\end{tabular}

The serum levels of Vitamin D, Calcium, IL-6, TNF- $a$ and Chemerin in the patients and healthy controls

The serum level of vitamin D was reduced in the patients compared with controls. The mean level in the patients was $16.44 \pm 4.73 \mathrm{ng} / \mathrm{ml}$ compared to $37.01 \pm 3.69 \mathrm{ng} / \mathrm{ml}$ in the controls. This reduction was statistically significant (Student's t-test $=25.88, \mathrm{P}<0.0001$ ).

The serum calcium was also reduced in patients relative to the controls with a mean value of $8.91 \pm 1.46$ $\mathrm{mg} / \mathrm{dl}$ versus $10.85 \pm 83 \mathrm{mg} / \mathrm{dl}$. This difference was statistically significant $(\mathrm{t}=4.9, \mathrm{P}<0.0001)$.

In the studied patients IL-6, TNF-a and Chemerin were significantly elevated in the serum compared with the healthy controls. The mean serum level of IL- 6 was $51.66 \pm 12.09 \mathrm{pg} / \mathrm{ml}$ in the patients compared to $4.65 \pm$ $1.78 \mathrm{pg} / \mathrm{ml}$ in the controls $(t=15.06, P<0.0001)$. The mean value of TNF-a was $42.15 \pm 18.76 \mathrm{pg} / \mathrm{ml}$ the patients versus $5.54 \pm 2.32 \mathrm{pg} / \mathrm{ml}$ in the controls $(\mathrm{t}=19.26, \mathrm{P}<0.0001)$ and the Chemerin mean value was $308.2 \pm 100.71 \mathrm{ng} / \mathrm{ml}$ in the patients compared to $177.9 \pm 36.98 \mathrm{ng} / \mathrm{ml}$ in the controls $(\mathrm{t}=11.21, \mathrm{P}<0.0001)$. (Fig. 1). 
The serum level of vitamin D was analyzed according to the different clinical and pathological features. There was no statistically significant relationship between the serum vitamin $D$ level and the patients' ages or their menopausal status, and the histopathological type of tumor. On the other hand, the serum level of vitamin $D$ was significantly reduced in tumors with high grade $(P<0.0001)$, patients with obesity $(P=$ 0.013), negative estrogen receptors $(E R)(P<0.0001)$, negative progesterone receptors $(P R)(P<0.0001)$, and positive HER2 receptors $(P<0.0001)$. It was also decreased in large tumors $(P<0.0001)$, patients with axillary lymph node involvement $(P<0.0001)$ and in the patients with advanced clinical stage $(P<0.0001)$ (Table 2). The reduced Vitamin $D$ level was significantly associated with bad prognostic features in breast cancer. The study of the serum calcium levels in our included breast cancer patients revealed no significant relation with the different clinical and pathological features. 
Table 2

The relations between the serum levels of vitamin $D$ and calcium, and different clinical and pathological features

\begin{tabular}{|lcccccccc|}
\hline & No. & \multicolumn{2}{l}{ Vitamin D } & P & \multicolumn{3}{ll}{ Calcium } & \\
\hline & & Mean & SD & & Mean & SD & \\
\hline Age group* & & & & & & & \\
\hline $20-30$ & 6 & 14.97 & 5.76 & 0.768 & 8.13 & 1.65 & 0.485 \\
\hline $31-40$ & 16 & 16.69 & 4.87 & & 7.99 & 1.52 & \\
\hline $41-50$ & 40 & 15.95 & 4.61 & & 8.45 & 1.47 & \\
\hline $51-60$ & 20 & 17.53 & 4.79 & & 8.86 & 1.1 & \\
\hline $61-70$ & 11 & 17.21 & 5.52 & & 8.21 & 1.27 & \\
\hline $71-80$ & 7 & 15.55 & 3.967 & & 7.97 & 1.73 & \\
\hline BM* & & & & & & & \\
\hline Normal weight & 29 & 16.76 & 3.45 & 0.013 & 8.89 & 1.12 & 0.087 \\
\hline Over weight & 34 & 15.54 & 4.34 & & 8.39 & 1.38 & \\
\hline Patients with obesity & 37 & 13.21 & 6.23 & & 8.12 & 1.59 & \\
\hline Menopausal Status** & & & & & & & \\
\hline Premenopaus & 47 & 16.09 & 4.73 & 0.498 & 8.32 & 1.51 & 0.709 \\
\hline Postmenopaus & 53 & 16.74 & 4.82 & & 8.43 & 1.34 & \\
\hline Pathology* & & & & & & & \\
\hline IDC & 84 & 16.67 & 4.72 & 0.175 & 8.38 & 1.46 & 0.982 \\
\hline ILC & 16 & 14.94 & 4.24 & & 8.37 & 1.24 & \\
\hline
\end{tabular}

Histopathological grade*

\begin{tabular}{|llllllll|}
\hline I & 24 & 21.7 & 3.62 & $<0.0001$ & 8.85 & 1.4 & 0.316 \\
\hline II & 27 & 17.64 & 2.25 & 8.18 & 1.54 & \\
III & 24 & 14.7 & 3.19 & & 8.24 & 1.25 & \\
IV & 25 & 11.7 & 2.97 & & 8.26 & 1.43 & \\
\hline
\end{tabular}

*One way ANOVA, **Student t-test. 


\begin{tabular}{|c|c|c|c|c|c|c|c|}
\hline & No. & \multicolumn{2}{|c|}{ Vitamin D } & $\mathbf{P}$ & \multicolumn{2}{|c|}{ Calcium } & $\mathbf{P}$ \\
\hline \multicolumn{8}{|c|}{ Estrogen receptors** (ER) } \\
\hline Positive & 84 & 17.63 & 4.19 & $<0.0001$ & 8.4 & 1.45 & 0.594 \\
\hline Negative & 16 & 10.15 & 1.58 & & 8.19 & 1.197 & \\
\hline \multicolumn{8}{|c|}{ Progesterone receptors** } \\
\hline Positive & 74 & 18.08 & 4.001 & $<0.0001$ & 8.45 & 1.39 & 0.376 \\
\hline Negative & 26 & 10.59 & 1.53 & & 8.17 & 1.48 & \\
\hline \multicolumn{8}{|c|}{ HER2 receptors** } \\
\hline Positive & 26 & 10.87 & 1.55 & $<0.0001$ & 8.4 & 1.45 & 0.594 \\
\hline Negative & 74 & 18.39 & 3.88 & & 8.19 & 1.19 & \\
\hline \multicolumn{8}{|l|}{$T^{*}$} \\
\hline T1 & 25 & 21.61 & 3.95 & $<0.0001$ & 8.88 & 1.38 & 0.115 \\
\hline $\mathrm{T} 2$ & 50 & 15.73 & 3.38 & & 8.18 & 1.39 & \\
\hline T3 & 25 & 12.96 & 3.74 & & 8.26 & 1.4 & \\
\hline \multicolumn{8}{|l|}{$\mathrm{N}^{*}$} \\
\hline NO & 36 & 20.48 & 3.75 & $<0.0001$ & 8.32 & 1.37 & 0.334 \\
\hline N1 & 31 & 15.84 & 2.59 & & 8.57 & 1.57 & \\
\hline N2 & 33 & 13.44 & 4.62 & & 8.03 & 1.39 & \\
\hline \multicolumn{8}{|l|}{ Stage* } \\
\hline I & 13 & 20.48 & 3.74 & $<0.0001$ & 8.41 & 1.35 & 0.801 \\
\hline IIA & 27 & 16.66 & 3.8 & & 8.6 & 1.54 & \\
\hline IIB & 27 & 14.76 & 2.93 & & 8.29 & 1.49 & \\
\hline IIIA & 33 & 9.75 & 1.38 & & 8.26 & 1.32 & \\
\hline
\end{tabular}

The relations between the serum levels of IL-6, TNF- $a$, Chemerin, and different clinical and pathological features

Evaluation of the serum level IL-6 in breast cancer patients revealed that it was significantly increased in patients with old age $(P<0.0001)$, patients with obesity $(P<0.0001)$. It is increased infiltrative lobular carcinoma (ILC) $(P<0.0001)$, in tumors with high histopathological grade $(P<0.0001)$, tumors with negative estrogen and progesterone receptors $(P<0.0001)$, tumors with HER2 positive receptors $(P<0.0001)$. In 
addition, it was elevated in patients with large size tumor $(P<0.0001)$, axillary lymph nodes infiltration $(P<$ $0.0001)$, and advanced clinical stage $(P<0.0001)$.

TNF-a serum level was significantly increased in the premenopausal patients $(P=0.029)$, patients with obesity $(P=0.0001)$, in the ILC pathology $(P<0.0001)$, in high-grade tumors $(P<0.0001)$, tumors with negative estrogen and progesterone receptors $(P<0.0001)$, tumors with HER2 positive receptors $(P<$ $0.0001)$. It was observed to significantly increase in patients with large size tumors $(P<0.0001)$, axillary lymph nodes involvement $(P<0.0001)$ and advanced tumor stage $(P<0.0001)$.

The serum level of the Chemerin was noted to be increased in patients with obesity $(P=0.0001)$, patients with ILC tumors $(P<0.0001)$, with undifferentiated tumors $(P<0.0001)$, with tumors with negative estrogen $(P<0.0001)$ and progesterone receptors $(P<0.0001)$, with positive HER2 receptors $(P<0.0001)$, with a large tumor size, axillary lymph nodes infiltration and advanced clinical stage $(P<0.0001)($ Table 3$)$. 
Table 3

The relations between the serum levels of IL-6, TNF-a, Chemerin and different clinical and pathological features

\begin{tabular}{|c|c|c|c|c|c|c|c|c|c|c|}
\hline & \multirow[t]{2}{*}{ No. } & \multicolumn{2}{|l|}{ IL-6 } & \multirow[t]{2}{*}{$\mathbf{P}$} & \multicolumn{2}{|l|}{ TNF- $a$} & \multirow[t]{2}{*}{$P$} & \multicolumn{2}{|c|}{ Chemerin } & \multirow[t]{2}{*}{$P$} \\
\hline & & Mean & SD & & Mean & SD & & Mean & SD & \\
\hline \multicolumn{11}{|l|}{ Age group* } \\
\hline $20-30$ & 6 & 24.56 & 19.65 & $\begin{array}{l}< \\
0.0001\end{array}$ & 36.45 & 23.0 & 0.171 & 294.1 & 54.69 & 0.611 \\
\hline $31-40$ & 16 & 31.14 & 14.47 & & 45.49 & 20.58 & & 307.2 & 42.08 & \\
\hline $41-50$ & 40 & 41.64 & 13.22 & & 45.99 & 16.24 & & 292.1 & 47.91 & \\
\hline $51-60$ & 20 & 41.64 & 13.22 & & 37.96 & 21.56 & & 282.0 & 52.00 & \\
\hline $61-70$ & 11 & 50.28 & 19.94 & & 43.07 & 14.69 & & 296.0 & 41.17 & \\
\hline $71-80$ & 7 & 64.41 & 7.1 & & 27.94 & 19.21 & & 274.0 & 49.04 & \\
\hline \multicolumn{11}{|l|}{ BMI* } \\
\hline $\begin{array}{l}\text { Normal } \\
\text { weight }\end{array}$ & 29 & 29.51 & 12.32 & $\begin{array}{l}< \\
0.0001\end{array}$ & 31.23 & 14.43 & 0.0001 & 231.11 & 47.56 & 0.0001 \\
\hline $\begin{array}{l}\text { Over } \\
\text { weight }\end{array}$ & 34 & 43.76 & 15.74 & & 38.43 & 16.22 & & 271.64 & 50.32 & \\
\hline $\begin{array}{l}\text { Patients } \\
\text { with } \\
\text { obesity }\end{array}$ & 37 & 58.56 & 17.32 & & 49.22 & 18.32 & & 288.94 & 58.91 & \\
\hline \multicolumn{11}{|c|}{ Menopausal Status ${ }^{\star \star}$} \\
\hline Premeno & 47 & 43.95 & 23.31 & 0.148 & 46.51 & 18.29 & 0.029 & 300.8 & 44.54 & 0.0606 \\
\hline Postmeno & 53 & 37.09 & 23.61 & & 38.28 & 18.68 & & 283.1 & 48.75 & \\
\hline \multicolumn{11}{|c|}{ Pathology** } \\
\hline IDC & 84 & 34 & 19.84 & $\begin{array}{l}< \\
0.0001\end{array}$ & 31.38 & 18.99 & 0.012 & 277 & 35.54 & $\dot{0}_{0.0001}$ \\
\hline ILC & 16 & 73.42 & 10.32 & & 44.2 & 18.24 & & 369.2 & 14.18 & \\
\hline \multicolumn{11}{|c|}{ Histopathological grade ${ }^{\star \star}$} \\
\hline I & 24 & 12.8 & 1.93 & $\begin{array}{l}<.0001 \\
0\end{array}$ & 27.15 & 13.77 & $\hat{0}_{0.0001}$ & 235.1 & 8.07 & $\dot{C}_{0.0001}$ \\
\hline II & 27 & 27.44 & 6.28 & & 30.65 & 16.03 & & 268.7 & 14.03 & \\
\hline III & 24 & 47.93 & 6.63 & & 53.11 & 11.89 & & 307.0 & 11.87 & \\
\hline
\end{tabular}

*One way ANOVA, **Student t-test. 


\begin{tabular}{|c|c|c|c|c|c|c|c|c|c|c|}
\hline \multirow[b]{2}{*}{ IV } & \multirow{2}{*}{$\begin{array}{l}\text { No. } \\
25\end{array}$} & \multicolumn{2}{|l|}{ IL-6 } & \multirow[t]{2}{*}{$\mathbf{P}$} & \multicolumn{2}{|l|}{ TNF-a } & \multirow[t]{2}{*}{$\mathbf{P}$} & \multicolumn{2}{|c|}{ Chemerin } & \multirow[t]{2}{*}{$\mathbf{P}$} \\
\hline & & 73.31 & 8.64 & & 55.74 & 14.19 & & 356.5 & 20.90 & \\
\hline \multicolumn{11}{|c|}{ Estrogen receptors ${ }^{\star \star}$} \\
\hline Positive & 84 & 33.03 & 17.98 & $\begin{array}{l}< \\
0.0001\end{array}$ & 39.26 & 18.21 & $\stackrel{<}{0.0001}$ & 277.0 & 35.54 & $\dot{0}_{0.0001}$ \\
\hline Negative & 16 & 78.55 & 5.64 & & 59.88 & 12.15 & & 369.2 & 14.18 & \\
\hline \multicolumn{11}{|c|}{ Progesterone receptors** } \\
\hline Positive & 74 & 28.91 & 14.89 & $\begin{array}{l}< \\
0.0001\end{array}$ & 37.85 & 18.31 & 0.0004 & 269.5 & 30.74 & $\dot{0}_{0.0001}$ \\
\hline Negative & 26 & 72.76 & 8.91 & & 52.18 & 16.38 & & 355.2 & 21.40 & \\
\hline \multicolumn{11}{|c|}{ HER2 receptors** } \\
\hline Positive & 26 & 72.76 & 8.911 & $\begin{array}{l}< \\
0.0001\end{array}$ & 37.79 & 18.15 & $\hat{0}_{0.0001}$ & 269.5 & 30.74 & $<.0001$ \\
\hline Negative & 74 & 28.91 & 14.89 & & 54.54 & 15.19 & & 355.2 & 21.40 & \\
\hline \multicolumn{11}{|l|}{$T^{*}$} \\
\hline T1 & 25 & 13 & 2.14 & $\begin{array}{l}< \\
0.0001\end{array}$ & 17.63 & 3.69 & $\begin{array}{l}< \\
0.0001\end{array}$ & 235.6 & 8.287 & $\begin{array}{l}< \\
0.0001\end{array}$ \\
\hline T2 & 50 & 37.46 & 11.94 & & 42.82 & 11.06 & & 287.5 & 22.77 & \\
\hline T3 & 25 & 73.31 & 8.64 & & 65.32 & 4.21 & & 356.5 & 20.90 & \\
\hline \multicolumn{11}{|l|}{$\mathrm{N}^{*}$} \\
\hline NO & 36 & 15.77 & 4.77 & $\begin{array}{l}< \\
0.0001\end{array}$ & 20.69 & 5.85 & $\hat{0}_{0.0001}$ & 241.6 & 11.78 & $\dot{0}_{0.0001}$ \\
\hline N1 & 31 & 38.34 & 7.56 & & 44.40 & 7.14 & & 290.6 & 12.68 & \\
\hline N2 & 33 & 68.94 & 10.91 & & 63.44 & 4.98 & & 347.6 & 24.17 & \\
\hline \multicolumn{11}{|l|}{ Stage* } \\
\hline I & 13 & 11.50 & 0.72 & $\begin{array}{l}<.0001 \\
0.0\end{array}$ & 14.61 & 1.832 & $\begin{array}{l}< \\
0.0001\end{array}$ & 229.2 & 5.996 & $\dot{0}_{0.0001}$ \\
\hline$\| A$ & 27 & 19.51 & 5.19 & & 25.62 & 5.378 & & 252.1 & 11.14 & \\
\hline IIB & 27 & 39.99 & 6.63 & & 45.91 & 6.339 & & 293.4 & 11.18 & \\
\hline IIIA & 33 & 65.53 & 8.86 & & 63.44 & 4.979 & & 347.6 & 24.17 & \\
\hline
\end{tabular}

Correlations between vitamin D and Calcium, IL-6, TNF- $a$, and Chemerin 
In the current study, we analyzed the relationship between the serum levels of vitamin D and calcium, IL-6, TNF- $a$, and chemerin. Pearson's correlation revealed a significant positive correlation between vitamin D deficiency and the serum levels of calcium $\left(r^{2}=0.298, P<0.0001\right)$, and significant negative correlation with IL-6 $\left(r^{2}=0.537, P<0.0001\right)$, TNF- $a\left(r^{2}=0.437, P<0.0001\right)$, and Chemerin $\left(r^{2}=0.484, P<0.0001\right)$. Figure 2 .

\section{Discussion}

Breast cancer is the most prevalent malignant tumor in women [1]. Vitamin D has an anti-inflammatory effect on the micro-environment of malignant cells [28]. Many of the pro-inflammatory cytokines induced by inflammation in the tumors can accelerate tumor progression, enhance angiogenesis, and suppress cell apoptosis [1].

Prediction of prognosis is one of the cornerstones for improving the outcome of breast cancer patients. Treatment adapting is an essential component for curing patients with poor prognosis and increasing their overall survival. In the current study, we explored the relationship between the serum levels of 25(OH)D, calcium, IL-6, TNF- $a$, and chemerin with breast cancer. We also studied their relationship with different clinical and pathological parameters to evaluate their association with breast carcinoma progression.

The influences of vitamin D on the inflammatory mechanisms in cancer were studied, several pathways were implicated. These pathways included the relationship between immune and cancer cells by controlling and regulating cytokine levels, inhibiting the nuclear factor-kappa B (NF-k B) signalling pathways, upregulation of Mitogen-Activated Kinase Protein 5 (MKP5), suppression of immune system cells, and inhibition of prostaglandins regulated mechanisms [29].

Analysis of our results showed a significant reduction in the serum levels of $25(\mathrm{OH}) \mathrm{D}$ and calci um in breast cancer patients compared to the controls $(P \otimes 0.0001)$. Vitamin $D$ reduction was significantly related to the adverse prognostic features in breast cancer as high histopathological tumor grade, large tumor size, positive axillary lymph nodes, negative estrogen and progesterone receptors, positive HER2 receptors, and advanced clinical stage $(P \otimes 0.0001)$.

Our study supports the results of Narvaez et al. [30]; Imtiaz and Siddiqui [31] who reported that vitamin D deficiency was observed in breast cancer patients. Moreover, de Sousa et al. [32], Colston and Hansen, [33], and Shaukat et al. [34] reported that lower vitamin D levels are related to a higher risk of breast malignancies. Quiroz et al. [35] revealed that vitamin D inhibits breast carcinogenesis through enhancement of apoptosis, suppression of angiogenesis, and malignant cell division. In breast malignancies, vitamin $D$ has a definite role through the estrogen receptors (ER) signaling pathways, as inhibition of aromatase enzyme expression in the mammary adipose tissues $[36,37]$. Besides, it decreases the expression of ER in breast cancer cells [38]. Interestingly, in ER-negative tumors, Vitamin D can also; induce ER expression and the tumor response to antiestrogen drugs [39].

Therefore, vitamin D may allow a protective role against breast cancer, which could be explained by the ability of vitamin $D$ to prevent the initiation of the malignant transformation by its anti-inflammatory, antioxidant defences, and by repairing the DNA damage [40, 41]. 
Our results revealed a significant decrease in the levels of serum calcium in our included patients. This observation was supported by Chen et al. that reported the protective function of calcium against breast cancer. This protective role could be explained by the chemo-preventive mechanism of active vitamin $D$, responsible for the regulation of calcium homeostasis [42].

One study reported that vitamin $\mathrm{D}$ and calcium supplementation reduce the percent of mammographic density (PMD) which is considered a risk factor for breast cancer, in premenopausal women [43]. Our results were also supported by Colston and Hansen, who observed an inverse relationship between the breast cancer risk and sunlight exposure that increases the dermal synthesis of vitamin $\mathrm{D}$ resulting in a reduction of the breast cancer risk [33]. On the other side, Chlebowski et al. [44] reported that there was no relation between 25(OH)D levels and breast cancer risk. Besides, vitamin $D$ and calcium supplementation in postmenopausal women didn't reduce the risk of breast cancer among them.

In the malignant microenvironment, inflammation is considered a cornerstone as the immune cells, and cytokines have a direct influence on malignant cell growth and migration $[45,46]$. In our patients, we noted

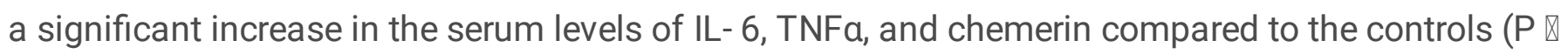
0.0001). We found a statistically significant link between these elevations and adverse prognostic parameters in breast cancer as infiltrative lobular carcinoma, high-grade tumors, negative hormone receptors (ER \& PR) tumors, positive HER2 tumors, T2 and T3 tumors, axillary lymph nodes involvement (N2 \& N3) and advanced TNM (IIB \& IIIA) clinical stage (P\0.0001).

In agreement with our results, Shuchen et al. [47] concluded that the higher levels of serum IL-6 were significantly related to breast cancer and its advanced stages. Furthermore, these results were associated with a poor prognosis of breast cancer. On the other hand, the study of Ahmad et al. [48], revealed that high IL- 6 and IL-10 levels were related to the features of good prognosis of breast cancer as small tumor size and low histopathological tumor grade. Some clinical studies reported high levels of serum TNF- $a$ in patients with breast cancer compared to healthy women [49]. Similarly, high levels of TNF-a messenger RNA expression were found in primary breast cancer, relative to normal breast tissue [50]. Kesler et al. [51] reported that IL- 6 and TNF-a levels were significantly increased in breast cancer patients compared to controls. Also, Yunfeng et al. [52] concluded that the higher levels of serum IL-6, IL-8, and TNF- $a$ are significantly associated with the clinical stage of breast cancer and with ER and HER2 expression by the tumors. Therefore, these cytokines were considered to be possible prognostic biomarkers of breast cancer.

There are controversial data about the relationship of chemerin to cancer. In agreement with our results, Sarmadi et al. [53] revealed chemerin has been recognized in breast cancer tissues and the proinflammatory cytokines, IL-1 $\beta$, TNF-a, IL-6, and especially interferon- $\gamma$ were up-regulated the chemerin expression in cancer tissues. Wang et al. [54] reported that high chemerin levels were linked with aggressive features of squamous cell cancer of the tongue such as advanced stage and increased tumorigenesis. On the other hand, Serkan et al. [55] noted that serum chemerin level was not associated with the stage of breast cancer. Also, Parolini et al.[56] suggested that the protective role of chemerin against cancer may be through enrolment of natural killer (NK) cells. So, through increasing chemerin levels, the immune system identifies the cancer cells and combats them. 
We analysed the correlation of serum levels of vitamin D with serum calcium, IL-6, TNFa, and chemerin in our series of patients. There was a significant positive correlation between serum 25(OH)D and calcium. Moreover, there was a significant negative correlation between serum 25(OH)D and IL-6, TNFa, and chemerin. BENETTI E et al. [57] suggested that vitamin D is a possible negative regulator of proinflammatory cytokines release. It suppresses the activation of nuclear factor- $\mathrm{KB}$ and therefore the transcription of its downstream pro-inflammatory cytokines.

\section{Conclusion}

We concluded that the vitamin D is the key regulator of pro-inflammatory cytokines (IL6, TNF-a and chemerin). Deficiency of vitamin D and increased inflammatory cytokines are associated with breast cancer progression.

\section{Recommendation}

Further studies are required to investigate the clinical significance of using vitamin D supplementation in early diagnosed or locally advanced breast cancer patients.

\section{Declarations}

\section{Acknowledgement:}

The authors would like to extend their sincere thanks to the Deanship of Scientific Research, Taif University for its funding of this research through the Research Group Project number 1-441-95

\section{Conflict of interest:}

None declared

\section{Ethics}

Informed written consent was taken from each participant in addition to the approval of the Research Ethics Committee of Taif University (approval no. 42-0010).

\section{References}

1. Sheikhpour R, Ghassemi N, Yaghmaei P, Ardekani JM, Shiryazd M. Immuno-histochemical assessment of P53 protein and its correlation with clinicopatho-logical characteristics in breast cancer patients. Indian Journal of Science and Technology. 2014 Apr 1;7(4):472.

2. Health Days 2020- Breast Cancer Awareness Month www.moh.gov.sa $\geq$ pages $\geq$ HealthDay-2020;10-0131. 
3. Mokdad AH, Jaber S, Aziz Ml, AlBuhairan F, AlGhaithi A, AlHamad NM, Al-Hooti SN, Al-Jasari A, AlMazroa MA, AlQasmi AM, Alsowaidi S. The state of health in the Arab world, 1990-2010: an analysis of the burden of diseases, injuries, and risk factors. The Lancet. 2014; Jan 25;383(9914):309-20.

4. Al-Daghri, N. M. Vitamin D in Saudi Arabia: prevalence, distribution and disease associations. J. Steroid Biochem.Mol. Bio. 2018; 175, 102-107.

5. Haneen Al-Alyani, Haifa A. Al-Turki, Omar N. Al-Essa, Fawaz M. Alani, and Mir Sadat-Ali. Vitamin D deficiency in Saudi Arabians: A reality or simply hype: A meta-analysis (2008-2015). J Family Community Med. 2018; 25(1): 1-4

6. Fuhrman BJ, Freedman DM, Bhatti P, Doody MM, Fu YP, Chang SC, et al. Sunlight, pol-ymorphisms of vitamin D-related genes and risk of breast cancer. Anticancer Res. 2013; 33(2):543-51.

7. Uzma Shamsi , Shaista Khan, Iqbal Azam, Aysha Habib Khan, Amir Maqbool, Moham-mad Hanif, Tiffany Gill, Romaina Iqbal, David Callen. A multicenter case control study of association of vitamin D with breast cancer among women in Karachi, Pakistan. PLoS ONE. 2020; 15(1): e0225402.

https://doi.org/10.1371/journal.pone.0225402

8. Grant WB. Roles of Solar UVB and Vitamin D in Reducing Cancer Risk and Increasing Survival. Anticancer Res. 2016; 36(3):1357-70. Epub 2016/03/16. PMID: 26977037.

9. Almquist, M.; Bondeson, A.-G.; Bondeson, L.; Malm, J.; Manjer, J. Serum levels of vitamin D, PTH and calcium and breast cancer risk-A prospective nested case-control study. Int. J. Cancer 2010, 127, 21592168.

10. Ene CD, Anghel AE, Neagu M, Nicolae I. 25-OH vitamin D and interleukin-8: emerging biomarkers in cutaneous melanoma development and progression. Mediators of inflammation. 2015 Jan 1;2015.

11. Christakos, Sylvia et al. "Vitamin D: metabolism." Endocrinology and metabo-lism clinics of North America vol. 39,2 2010: 243-53, doi:10.1016/j.ecl.2010.02.002

12. Gyetko MR, Hsu CH, Wilkinson CC, Patel S, Young E. Monocyte 1a-hydroxylase regulation: induction by inflammatory cytokines and suppression by dexame-thasone and uremia toxin. Journal of leukocyte biology. 1993 Jul;54(1):17-22.

13. Heine G, Niesner U, Chang HD, Steinmeyer A, Zügel U, Zuberbier T, Radbruch A, Worm M. 1, 25dihydroxyvitamin D3 promotes IL-10 production in human B cells. European journal of immunology. 2008 Aug;38(8):2210-8.

14. Spach KM, Nashold FE, Dittel BN, Hayes CE. IL-10 signaling is essential for 1, 25-dihydroxyvitamin D3mediated inhibition of experimental autoimmune enceph-alomyelitis. The Journal of Immunology. 2006 Nov 1;177(9):6030-7. 
15. Peterson CA, Heffernan ME. Serum tumor necrosis factor-alpha concentrations are negatively correlated with serum $25(\mathrm{OH})$ D concentrations in healthy women. Journal of inflammation. 2008 Dec;5(1):1-9.

16. Milovanovic M, Pesic G, Nikolic V, Jevtovic-Stoimenov T, Vasic K, Jovic Z, Del-janin-llic M, Pesic S. Vitamin D deficiency is associated with increased IL-17 and TNFa levels in patients with chronic heart failure. Age (years). 2012 Mar; 1:1(58):44-66.

17. Tang J, Zhou RU, Luger D, Zhu W, Silver PB, Grajewski RS, Su SB, Chan CC, Ado-rini L, Caspi RR. Calcitriol suppresses antiretinal autoimmunity through inhibito-ry effects on the Th17 effector response. The Journal of Immunology. 2009 Apr; 15:182(8):4624-32.

18. Yssel H, Malefyt RD, Roncarolo MG, Abrams JS, Lahesmaa R, Spits H, De Vries JE. IL-10 is produced by subsets of human CD4+ T cell clones and peripheral blood T cells. The Journal of Immunology. 1992 Oct 1;149(7):2378-84.

19. Kovacs E. Investigation of interleukin-6 (IL-6), soluble IL-6 receptor (sIL-6R) and soluble gp130 (sgp130) in sera of cancer patients. Biomedicine \& pharma-cotherapy. 2001 Sep 1;55(7):391-6.

20. Arias JI, Aller MA, Arias J. Cancer cell: using inflammation to invade

the host. Mol Cancer. 2007;6:29.

21. Wittamer .V, Gregoire F, Robberecht P, Vassart G, Communi D, Parmentier M. The C-terminal nonapeptide of mature chemerin activates the chemerin recep-tor with low nanomolar potency. J Biol Chem 2004; 279(11): 9956-9962.

22. Rourke JL, Dranse HJ, Sinal CJ. Towards an integrative approach to understand-ing the role of chemerin in human health and disease. Obesity Rev 2013; 14 245-262.

23. Zabel, B. A., Kwitniewski, M., Banas, M., Zabieglo, K., Murzyn, K., and Cichy, J. Chemerin regulation and role in host defense. Am. J. Clin. Exp. Immunol. 2014; 3, 1-19.

24. Brahmkhatri VP, Prasanna C, Atreya HS. Insulin-like growth factor system in cancer: novel targeted therapies. Biomed Res Int. 2015;2015:538019-24.

25. Soria G, Ofri-Shahak M, Haas I, et al. Inflammatory mediators in breast

cancer: coordinated expression of TNFa \& IL-1 $\beta$ with CCL2 \& CCL5

and effects on epithelial-to-mesenchymal transition. BMC Cancer.2011;11:130.

26. Hu K, Callen DF, Li J, Zheng H. Circulating Vitamin D and Overall Survival in Breast Cancer Patients: A Dose-Response Meta-Analysis of Cohort Studies. In-tegr Cancer Ther. 2018; 17(2):217-25.

27. Breast AJCC (2002) Cancer staging manual. In: American Joint Committee on Cancer, 6th ed. Springer, New York, pp 171-180. 
28. Diaz L, Diaz-Munoz M, Garcia-Gaytan AC, Mendez I. Mechanistic effects of calcitriol in cancer biology. Nutrients. 2015;7:5020-5050.

29. Han Y, Zhang Y, Jia T, Sun Y. Molecular mechanism underlying the tumor-promoting functions of carcinoma-associated fibroblasts. Tumor Biology. 2015 Mar 1;36(3):1385-94.

30. Narvaez CJ, Matthews D, LaPorta E, Simmons KM, Beaudin S, Welsh J. The im-pact of vitamin D in breast cancer: genomics, pathways, metabolism. Frontiers in physiology. 2014 Jun 13;5:213.

31. Imtiaz S, Siddiqui N. VITAMIN-D STATUS AT BREAST CANCER DIAGNOSIS: COR-RELATION WITH SOCIAL AND ENVIRONMENTAL FACTORS AND DIETRY INTAKE. Journal of Ayub Medical College Abbottabad. 2014 Jun 1;26(2):186-90.

32. de Sousa Almeida-Filho B, De Luca Vespoli H, Pessoa EC, Machado M, Nahas-Neto J, Nahas EAP. Vitamin $D$ deficiency is associated with poor breast cancer prognostic features in postmenopausal women. J Steroid Biochem Mol Biol. 2017 Nov;174:284-289. doi: 10.1016/j.jsbmb.2017.10.009. Epub 2017 Oct 12. PMID: 29031688.

33. Colston KW. Mechanisms implicated in the growth regulatory effects of vitamin $D$ in breast cancer. Endocrine-related cancer. 2002 Mar 1;9(1):45-59.

34. Shaukat N, Jaleel F, Moosa FA, Qureshi NA. Association between vitamin D defi-ciency and breast cancer. Pakistan journal of medical sciences. 2017 May;33(3):645.

35. Garcia-Quiroz J, Rivas-Suarez M, Garcia-Becerra R, et al. Calcitriol reduces thrombospondin-1 and increases vascular endothelial growth factor in breast can-cer cells: implications for tumor angiogenesis. $J$ Steroid Biochem Mol Biol. 2014;144(Pt
A):215-222.

36. Krishnan AV, Swami S, Peng L, Wang J, Moreno J, Feldman D. Tissue-selective regulation of aromatase expression by calcitriol: implications for breast cancer therapy. Endocrinology. 2010;151:32-42.

37. Swami S, Krishnan AV, Wang JY, et al. Inhibitory effects of calcitriol on the growth of MCF-7 breast cancer xenografts in nude mice: selective modulation of aromatase expression in vivo. Horm Cancer. 2011;2:190-202.

38. Swami S, Krishnan AV, Peng L, Lundqvist J, Feldman D. Transrepression of the estrogen receptor promoter by calcitriol in human breast cancer cells via two neg-ative vitamin $\mathrm{D}$ response elements. Endocr Relat Cancer. 2013;20: 565-577.

39. Santos-Martinez N, Diaz L, Ordaz-Rosado D, et al. Calcitriol restores antiestro-gen responsiveness in estrogen receptor negative breast cancer cells: a potential new therapeutic

approach. BMC Cancer. 2014;14:230.

Page 19/23 
40. Feldman D, Krishnan AV, Swami S, Giovannucci E, Feldman BJ. The role of vitamin D in reducing cancer risk and progression. Nature reviews cancer. 2014 May;14(5):342-57.

41. Giammanco M, Di Majo D, La Guardia M, Aiello S, Crescimannno M, Flandina C, Tumminello FM, Leto G. Vitamin D in cancer chemoprevention. Pharmaceuti-cal biology. 2015 Oct 3;53(10):1399-434.

42. Chen P, Hu P, Xie D, Qin Y, Wang F, Wang H. Meta-analysis of vitamin D, calci-um and the prevention of breast cancer. Breast cancer research and treatment. 2010 Jun 1;121(2):469-77.

43. Bérubé S, Diorio C, Mâsse B, Hébert-Croteau N, Byrne C, Côté G, Pollak M, Yaffe M, Brisson J. Vitamin D and calcium intakes from food or supplements and mammographic breast density. Cancer Epidemiology and Prevention Bi-omarkers. 2005 Jul 1;14(7):1653-9.

44. Chlebowski RT, Johnson KC, Kooperberg C, Pettinger M, Wactawski-Wende J, Rohan T, Rossouw J, Lane D, O'Sullivan MJ, Yasmeen S, Hiatt RA. Calcium plus vitamin D supplementation and the risk of breast cancer. JNCl: Journal of the National Cancer Institute. 2008 Nov 19;100(22):1581-91.

45. Hanahan D, Weinberg RA. Hallmarks of cancer: the next generation. cell. 2011 Mar 4;144(5):646-74.

46. Chen F, Zhuang $X$, Lin L, Yu P, Wang Y, Shi Y, Hu G, Sun Y. New horizons in tumor microenvironment biology: challenges and opportunities. BMC medicine. 2015 Dec;13(1):45.

47. Shuchen Lin, Z. Gan, K., Han, Y. Yao, D. Min. Interleukin-6 as a Prognostic Marker for Breast Cancer: A Meta-analysis. Tumori Journal. 2015;101:535 - 541.

48. Ahmad N, Ammar A, Storr SJ, Green AR, Rakha E, Ellis IO, Martin SG. IL-6 and IL-10 are associated with good prognosis in early stage invasive breast can-cer patients. Cancer Immunology, Immunotherapy. 2018 Apr 1;67(4):537-49.

49. Alfano CM, Peng J, Andridge RR, Lindgren ME, Povoski SP, Lipari AM, Agnese DM, Farrar WB, Yee LD, Carson WE, Kiecolt-Glaser JK 3rd. Inflamma-tory cytokines and Comorbidity development in breast cancer survivors versus noncancer controls: evidence for accelerated aging? J Clin Oncol. 2017;35:149-56.

50. Yu M, Zhou X, Niu L, Lin G, Huang J, Zhou W, Gan H, Wang J, Jiang X, Yin B, Li Z. Targeting transmembrane TNF-alpha suppresses breast cancer growth. Cancer Res. 2013;73:4061-74.

51. Kesler S, Janelsins M, Koovakkattu D, Palesh O, Mustian K, Morrow G, Dha-bhar FS. Reduced hippocampal volume and verbal memory performance associ-ated with interleukin- 6 and tumor necrosis factor-alpha levels in chemotherapy-treated breast cancer survivors. Brain Behav Immun. 2013 Mar;30 Suppl(0):S109-16.

52. Yunfeng Ma, Yi Ren, , Zhi-Jun Dai, Cai-Jun Wu, Yan-Hong Ji, Jiru Xu. IL-6, IL-8 and TNF-a levels correlate with disease stage in breast cancer patients. Adv Clin Exp Med. 2017, 26 (3):421-426. 
53. Sarmadi P, Tunali G, Esendagli-Yilmaz G, et al. CRAM-A indicates IFN-gamma-associated inflammatory response in breast cancer. Mol Immun. 2015, 68(2 Pt C): 692-698.

54. Wang N, Wang QJ, Feng YY, et al. Overexpression of chemerin was associated with tumor angiogenesis and poor clinical outcome in squamous cell carcinoma of the oral tongue. Clinical Oral Investig. 2014, 18: 997-1004.

55. Serkan AKIN, Safak AKIN, Emre GEDIK, Elif HAZNEDAROGLU, Ayse L. DOGAN, Mustafa K. ALTUNDAG. Serum Chemerin Level in Breast Cancer. International Journal of Hematology and Oncology, 2017, 27 (2): 127-132.

56. Parolini S, Santoro A, Marcenaro E, et al. The role of chemerin in the colocaliza-tion of NK and dendritic cell subsets into inflamed tissues. Blood, 2007. 109: 3625-3632.

57. Benetti E., Mastrocola R., Chiazza F., Nigro D., D'antona G., Bordano V., Fan-tozzi R., Aragno M. and Minetto M.: Effects of Vitamin D on insulin resistance and myosteatosis in diet-induced obese mice. PLoS One. 2018, 13 (1): e0189707.

\section{Figures}




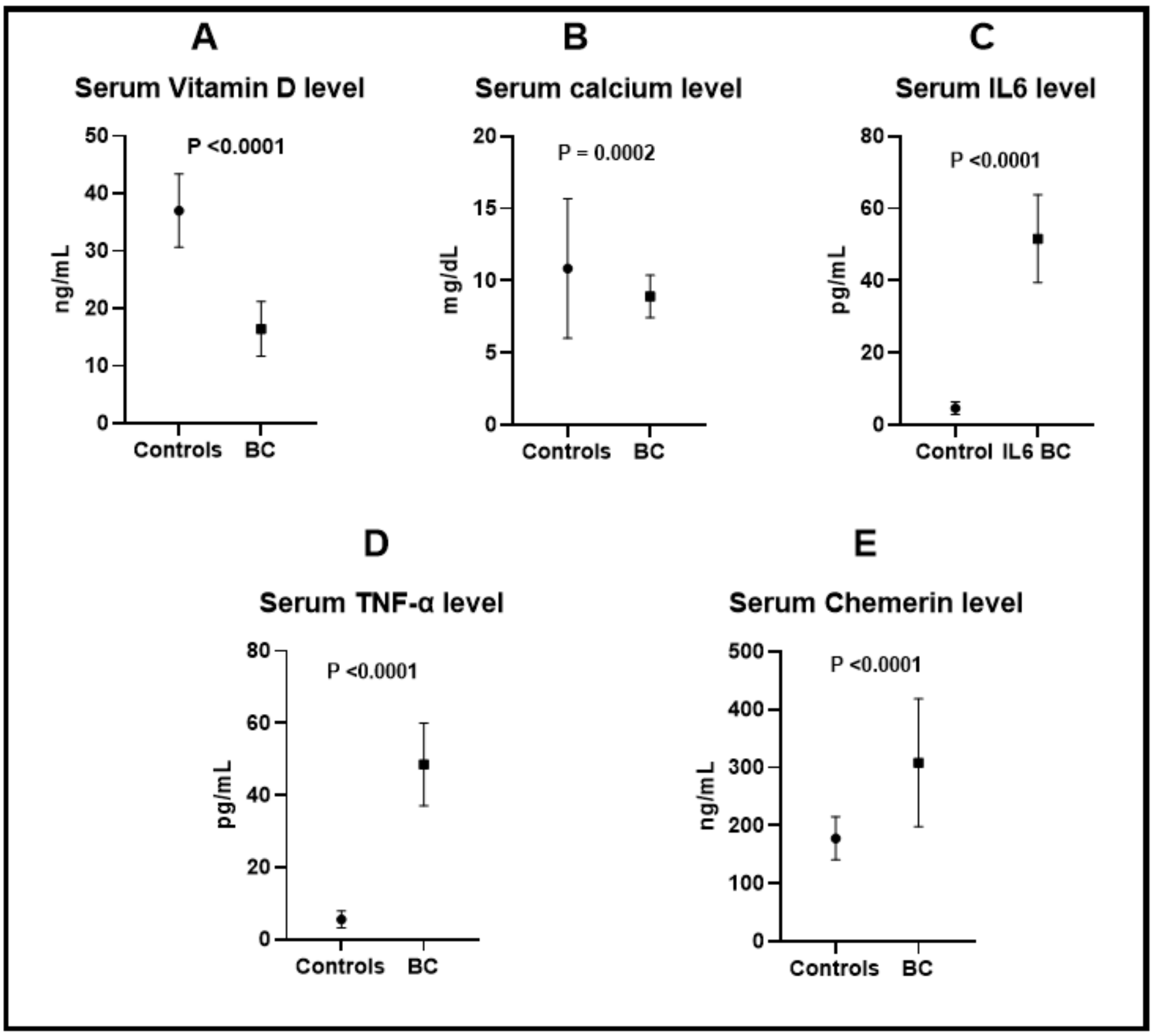

Figure 1

Represent in the serum levels of Vitamin D, Calcium, IL-6, TNF-a, and Chemerin in the breast cancer patients and the healthy controls (BC: breast cancer) 
A

Pearson's correlation between the serum levels of vitamin D and Calcium

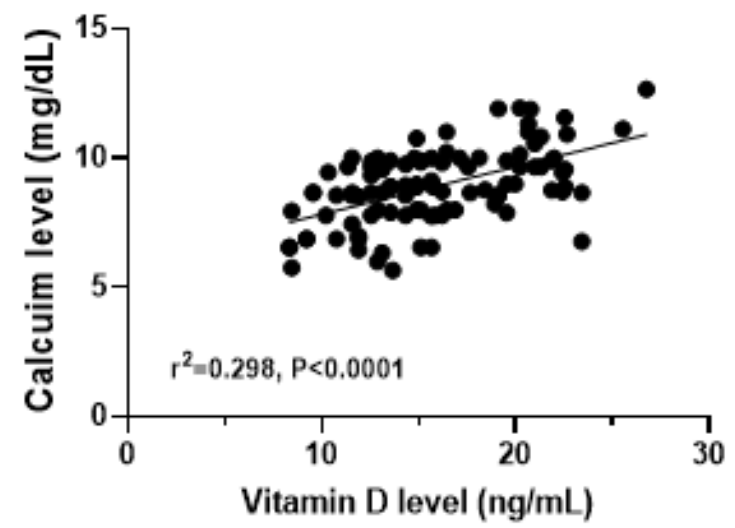

C

Pearson's correlation between the serum levels of vitamin D and TNF- $\alpha$

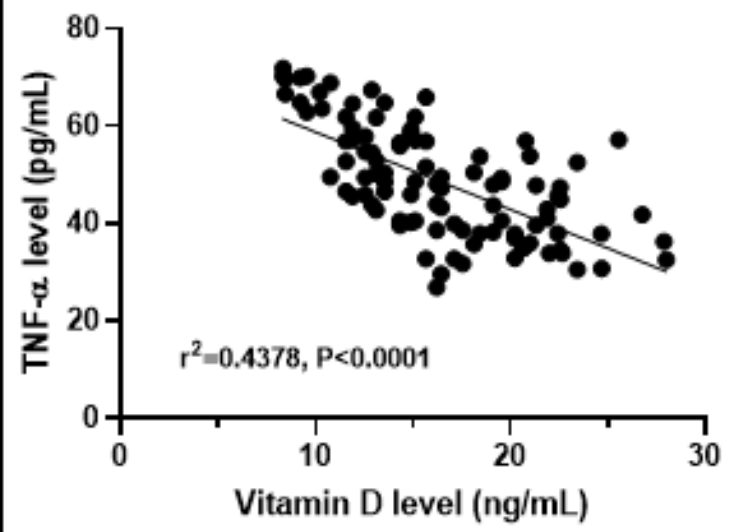

B

Pearson's correlation between the serum levels of vitamin D and IL-6

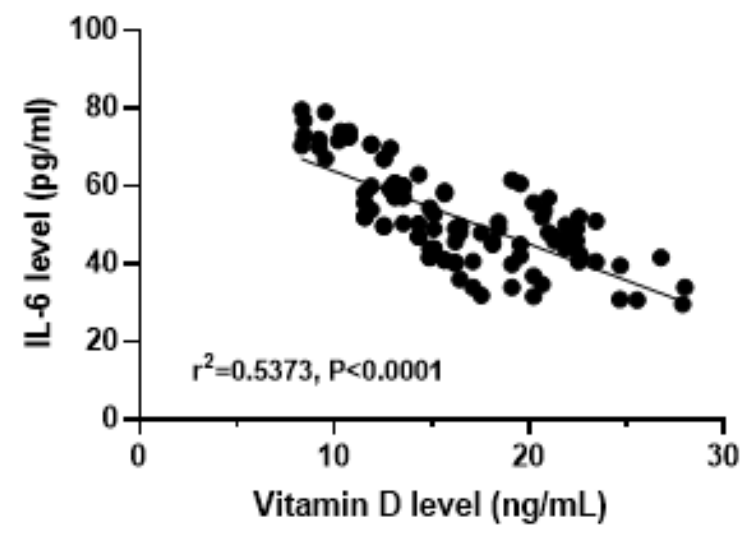

D

Pearson's correlation between the serum levels of vitamin $D$ and Chemerin

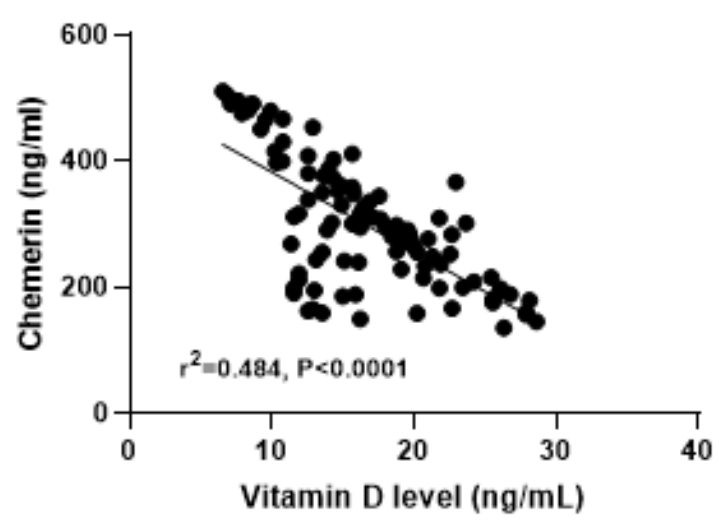

Figure 2

Pearson's correlation between serum vitamin D levels and serum calcium (A), serum IL-6 (B), serum TNF-a (C), and serum Chemerin (D). 